\title{
Secured residential enclaves in the Delhi region Impact of indigenous and transnational models
}

\section{Véronique Dupont}

Institut de Recherche pour le Développement (IRD), CESSMA

Email: veronique.dupont@ird.fr

Contact address: CESSMA (Centre for social sciences studies on Africa, Asia and America)

Université Paris Diderot, Case courrier 7017

75205 PARIS Cedex 13

\begin{abstract}
:
This paper examines the development of secured residential enclaves in India, especially in Delhi. It expounds the conditions of their emergence and success: although gated communities are a market driven development boosted by economic liberalisation reforms, they are also embedded in indigenous traditions of residential segregation and enclosure as well as colonial practices. The Non Resident Indians have further played a significant role in the production of these new residential spaces. Significant appeal factors are explored: desire for security, retreat from failing government and the polluted city, search for exclusivity, elitism and social homogeneity. Tapping into the Indian diaspora market and the middleclass' aspirations for social status, promoters have projected their residential enclaves as a way of "global living" in a healthy environment, reserved to a privileged cosmopolitan elite. Yet, gated communities in Delhi are not a mere exogenous western production; rather, they are spaces in-between the global and the local. The findings are based on direct field observations in Delhi and a review of advertisements by real estate developers in various media. The analysis pursues an Indo-Chinese comparative perspective with reference to the research of Marie Sander (this issue) on gated communities in Shanghai.
\end{abstract}

Key words:

Segregation ; Gated communities ; Non Resident Indians ; Delhi ; Comparative urbanism

\section{Highlights}

- $\quad$ Secured residential enclaves in Indian metros are not a mere exogenous western production, but spaces in-between the global and the local.

- $\quad$ They are a market driven development boosted by economic liberalisation reforms.

- They are also embedded in indigenous traditions of residential segregation and enclosure as well as colonial practices, especially in Delhi.

- Non Resident Indians have played a significant role, including symbolic, in the production and promotion of gated communities.

- $\quad$ Significant appeal factors include desire for security, retreat from failing government and the polluted city, search for prestige and distinction. 


\begin{abstract}
Malibu Condominiums. American-Style Luxury Apartments. ${ }^{1}$
Malibu Towne: Planned and developed by ex-NRI Californian. American suburban ambience. Malibu Towne has been designed to include cul-de-sacs and extensively landscaped to create the ambience of a typical lush green American housing development. ${ }^{2}$

Sagar Estate's Riverdale - America — East of Delhi: Citizenship opens today.

Today we are laying the foundation of a New America, east of Delhi.

The all-America condominium style of life now comes to India. [...]

Riverdale is planned and designed by the Canada-based architect, Ramesh Khosla. [...]

Citizenship is open today to all who like to live in America. [...] this condominium

captures the spirit of liberty like no other.

Luxury and comfort, till now only seen west of the Atlantic. Now, east of Delhi. ${ }^{3}$
\end{abstract}

These slogans, drawn from two advertisements published in 1995 in the Delhi edition of leading newspapers to sell luxury apartments in new condominiums on the outskirts of the Indian capital, could not have been found in Chinese media even today - especially the second one. Although the rise of secured residential enclaves inspired by the North American model of gated communities is a market-led development common to both countries and which was boosted by economic reforms, the production and promotion of such type of highstanding residential complexes in India bear some distinctive features. For instance, the overt uncritical reference to the American life-style and its "spirit of liberty" would be out of place in the Communist People's Republic of China. These advertisements also highlight a specific figure of the Indian urban scene, the 'NRI', or Non Resident Indian. These are, legally speaking, Indian citizens living abroad (expatriate Indians) although in common usage this category often includes people of Indian origin who are citizens of other countries as well NRIs thus becomes a synonym for the Indian diaspora, estimated to be over 25 million people.

In this paper, I shall examine from a comparative perspective the development of secured residential enclaves in India, more specifically in the Delhi region, focusing on some selected issues analysed by Marie Sander in this volume for gated communities in Shanghai. I will first expound the conditions of emergence and success of gated communities in India, with a discussion similar to the development of this housing model in China: to which extent is it a new imported western concept, or the outcome of a historical evolution rooted in indigenous social and cultural tradition? I will then focus on the role of NRIs in the production of new residential forms - the NRI category is certainly more relevant in the Indian context than that of expatriates, which are the focus of Sander's study. Lastly, I will engage with a discussion on the appeal of gated communities with a view to contribute to an Indo-Chinese comparative perspective. Thus, with reference to general debates in the context of North America, Europe as well as emerging countries (Atkinson and Blandy, 2006; Cséfalvay 2011; Cséfalvay and Webster, 2012; Glasze, Webster and Frantz, 2006), I will explore in the case of Delhi the relevance of some main factors identified or discussed by Sander (this volume) and other authors in the Chinese context (Wu, 2005, 2010). These factors include desire for security; retreat from failing government and from the polluted city; search for exclusivity, elitism and social homogeneity.

The analyses on Delhi presented here are based on a combination of several sources: direct field observations in the Delhi region spread over the years since 1993, including a systematic migration survey conducted in DLF City in 1995 that covered a representative sample of 164 
households and was completed with in-depth interviews conducted by Mriga Sidhu in 1997 as part of the same research project (Dupont, 2005; Sidhu, 1997); and a systematic review of advertisements and press articles in the Delhi edition of the mainline English medium newspapers from 1994 to 1998, as well as publicity hoardings, brochures and websites of real estate developers operating in the Delhi region, with periodic up-dating till 2011. This was completed by secondary sources (such as, regarding Delhi: King, 2002, 2004; Brosius, 2010). Investigations focus first on the 1990s, which represented in India a strategic period especially in the urban sector, with the emergence of new urban developments and residential forms in a context of economic liberalisation, as explained in the first part of the paper. Follow-up observations during the succeeding decade help confirm or nuance some of the early trends.

Through this analysis of the development of gated communities, my objective is to reflect on the production of "in-between spaces" as part of global-city formation in Asia. I will argue that the production of such secured residential enclaves in Indian globalizing metropolises epitomizes the creation of blended spaces bearing the influence of transnational cultures (Appadurai, 1996; King, 2002) as well as indigenous urbanism and reinvented Indian culture. Further, it also reveals the gap between aspirations to "global living" and everyday challenges of the developmental mega-city, as well as the deepening gap between an aspirational urban middle-class and the excluded 'others' against whom walls and fences are erected.

\section{CONTEXTUALIZING "GATED COMMUNITIES" IN INDIA}

This first part attempts to draw a brief genealogy of the forms and processes of residential segregation in Indian cities, including practices of enclosure and the development of residential enclaves, with a special emphasis on Delhi.

\section{'Gated Communities' in the Indian Context: What Do We mean?}

Preliminary clarifications on the type of housing estates which may be labelled 'gated communities' in the India context are useful for a comparative perspective. Varrel (2008: chapter 7) distinguishes two types of exclusive residential enclaves: the first one includes condominiums, e.g. blocks of flats often with high-rise buildings; while the second consists of plotted development with independent villas or row houses. Both types share similar features: the buildings or houses are constructed by the same private real estate developer and its team of architects; they are integrated in a secured compound with restricted access provided by a fence or walls as well as gates with guards; they are equipped with collective amenities and services for the exclusive use of the residents; and they are privately managed. Depending on the authors, the label 'gated communities' is applied only to enclosed estates of villas, or to enclosed condominium clusters as well. In this paper, I shall use the term 'gated communities' in its larger acceptation to encompass residential enclaves with the above characteristics. In the Delhi region, condominium clusters are more frequent than compounds of villas, which require much more space for an equivalent number of dwelling units. Interestingly too, as far as the Indian National Capital region is concerned, 'gated community' was a term hardly found in the language mobilised by the developers for their publicity in the 1990s; they rather used the words condominiums, township or (mini)city, further qualified by adjectives like self-contained or integrated, and exclusive or for the elite (Dupont, 2005; see also the last section of this paper). The label 'gated community' has now spread among real estate developers in India, for example for the promotion of the famous Commonwealth 
Games Village 2010 residential complex built by Emaar MGF (a Dubai-based real estate developer) that includes a series of 34 towers and is presented as "one of the first exclusive gated communities in Delhi" on their internet video ${ }^{4}$.

The first condominiums introduced in Indian metropolises were built in Mumbai by the firm Ansal Housing in 1982 (Varrel, 2008: 291). Condominiums differ from the usual residential multi-storeyed buildings commonly found in India cities such as, in Delhi, the Cooperative Group Housing Society residential complexes built on land leased out by the Delhi Development Authority (DDA) since the 1980s. The latter have specific modalities of production and management (see below) and provide only basic collective facilities, although both have in common the - more or less- secured compound.

\section{Development of Gated Communities in the Delhi Region}

Several factors have contributed to the development of market driven residential enclaves in India. The liberalisation of the economy and the opening to foreign capital investment from the 1990s, facilities of investments for Non Resident Indians, credit deregulation, the establishment of multinational companies in the larger metropolises, and the rise of a new urban middle class ${ }^{5}$ all concurred and conduced to an unprecedented real estate boom (despite ups and downs) and to the production of new residential spaces and architectural forms, including gated communities and condominiums (King, 2002; Milbert, 2009; Wissink, 2013).

In the Delhi region, the most spectacular changes in real estate development (for residential as well as commercial and business purposes) occurred initially in the outlying districts, especially in Gurgaon and Noida, where new private neighbourhoods have emerged. The DDA's control over all land within the 'urbanisable' limits of Delhi under the 1961 urban land policy - a scheme for large-scale acquisition, development and disposal of landprompted the choice of locations outside the National Capital Territory of Delhi. The development of residential estates in distant rural fringes was further facilitated by the tremendous increase in private cars, which reflected the rise of the middle classes in Delhi. In the bordering states of Haryana and Uttar Pradesh, building societies could acquire large tracts of land in keeping with the development plan of the metropolitan area, seeking population deconcentration. For example, Delhi Land and Finance (DLF), a prime land developer of Delhi in the 1950s, planned in Gurgaon its DLF City spread over 1100 hectares and branded as "Asia's largest private township".

In the 1990s, there was a shortage of constructible land for private developers in the capital proper. Consequently, condominiums and other exclusive residential enclaves started mushrooming in the outskirts of Delhi, and offered financially attractive options for prospective property owners. Those options remained more affordable, with interesting instalment schemes, as compared especially to the prices of houses in South Delhi's well-off localities, in neighbourhoods much sought after by the rich because of the social status that they confer on their residents. The prestige and status attached to the new suburban residential enclaves rendered them an attractive alternative for the middle and upper classes.

Many buyers, including those among the diaspora, could also find lucrative options of investment in this upper segment of the urban real estate market, including for rental purposes. Real estate prices in the Delhi region have registered a spectacular rise since the 1990s. Speculation has been boosted by the expansion of road and metro infrastructure, most recently in the context of the transformations of the capital for hosting the 2010 
Commonwealth Games, and in the broader context of an aspiring 'global', 'world-class' and 'slum-free city' (Dupont, 2011).

In line with economic reforms at the national level, the Master Plan for Delhi 2021 (DDA 2007) promoted the involvement of the private sector as developer and builder. As a result, significant real estate developments, notably the construction of high-end condominium clusters, now affect urban land reclaimed from spaces in the capital proper. These include reclaimed built-up areas such as slums ${ }^{6}$ and mill lands ${ }^{7}$, as well as controversial constructions in ecologically sensitive zones, for instance in the Yamuna river floodplain where the Commonwealth Games Village Complex was built ${ }^{8}$ (See Figure 2).

\section{Historical Perspective on Residential Segregation in India}

The development of post-liberalisation gated communities in Indian cities reflects a contemporary global trend. At the same time, this type of residential enclave draws on a tradition of segregation rooted in Indian society and on practices of enclosure with a long precolonial and colonial history, with post-colonial ramifications.

The Hindu socio-religious hierarchy underpinning the traditional caste system implies a segmentation and hierarchy of space. Sanskrit treatises and vastu principles of architecture recommended spatial separation of castes (Begde, 1978). Although, in cities, segregation was not always rigorously observed, the lines separating the castes at either end of the hierarchy have always been extremely clear. The Brahmins have invariably benefited from special treatment (their neighbourhoods were usually located next to the temple) while at the other end of the social ladder, the untouchable castes were kept apart, relegated to the periphery. The Harijan bastis, the colonies where the formerly untouchable castes -the Scheduled Castes or Dalits- live, are still an urban reality. In pre-industrial cities of northern India, central neighbourhoods were segmented into enclosed blocks that housed the members of a specific religious community or a caste, and each block was entered through a gate that could be closed (for instance mohallas in Delhi, pols in Ahmedabad). During the colonial period, British urbanism in India rested on the principle of separation of the 'white city' from the 'black city' (native city) - residential segregation between Europeans and 'Natives' was indeed one of the guiding principles of colonial urban planning (Evenson 1989, Christopher, 2005).

The geographies of cities in the Indian subcontinent have been further marked and redefined by communal violence, which culminated during the Partition of 1947, affecting the Hindu, Sikh and Muslim communities. In the post-independence period, new urban episodes of communal riots entailed intra-city migration and strengthened a pattern of residential segregation, especially self-segregation among the Muslims, "who have been searching for safety in numbers" (Gayer and Jaffrelot, 2012: 12). In Delhi, the Sikh carnage that followed the assassination of Prime Minister Indira Gandhi in 1984 also contributed to the search for more secured neighbourhoods (Kothari and Sethi, 1985). Fear and mistrust of the 'others' further led to the erection of concrete walls and gates in some places, as documented in Ahmedabad after the 2002 anti-Muslim pogrom (Mahadevia 2007; Jaffrelot and Thomas, 2012). The trauma of communal violence may turn neighbourhood security into an imperative, while exclusionary closure engenders a process of "ghettoisation" (Gayer and Jaffrelot, 2012: 21).

\section{Residential Segregation and Enclosure Practices in Delhi Throughout the $20^{\text {th }}$ Century}


Focussing back on the case of Delhi, the building of New Delhi by the British in the 1910s and 20s provides a revealing example of colonial town planning based on segregation. The new imperial capital was deliberately built separate from the existing 'native' town, Old Delhi. A wide stretch of land was cleared and left undeveloped, and was used to mark the boundary between the two urban areas. In New Delhi, the spatial organisation of housing for civil servants directly reflected one's position within the hierarchy. Moreover, housing for British employees was separate from that of Indian employees, with the latter housed the farthest away from the vice-regal palace (Evenson, 1989). After Independence, since the early 1950s, the government also built housing estates for its employees (who represented a very significant share of the working population in the national capital, owing to its administrative functions), and reproduced a similar type of segregated residential pattern. Many such residential colonies were constructed in the southern part of Delhi. They have engendered a pattern of residential segregation, not only between government employees and other workers, but also among the government employees themselves since they have been supplied with different categories of housing according to their official status and range of income. This specific feature of the urban landscape of Delhi, and its consequences in terms of segregation along socio-economic lines, has been even qualified as "salaried apartheid" by Mitra (1970; also quoted by Nagpaul, 1988: 188).

Among the various types of modern collective housing that have developed in Delhi, the apartment blocks built and managed by co-operative group housing societies illustrate combined practices of residential clustering and filtering, leading to segregation (Dupont, 2004). The constitution of the co-operative societies was based on an association of prospective flat buyers who belonged to similar social or professional networks, and usually shared some common attributes. Very frequently the association was formed on the basis of a common professional affiliation: lawyers of the Supreme Court, employees from the same press group, or the same institute, officers from the police, high-ranking government officers, or teachers from the same university, for instance. The founding group was then in a position to exert control on the selection of new buyers, while the owners renting out their flats applied a screening process on prospective tenants. This system of co-optation and selection ensured, at least in the beginning, social and professional homogeneity among residents in the same complex of apartment blocks. A filtering procedure applies also to visitors as fences or walls enclose these residential complexes, with gates and watchmen controlling all people entering.

Similar concerns for security and protection from 'outsiders' are found in wealthy residential neighbourhoods. Thus, the enclosure of spaces that are not private estates behind fences and gates, including the public streets that pass through them, is a rising trend observed in Delhi (and other Indian cities) since the turn of the last millennium.

In short, residential segregation in Indian cities like Delhi is a long-standing phenomenon, that results from different kinds of factors: socio-cultural factors and politico-religious tensions; town planning, housing policies and market forces; as well as household residential aspirations leading to strategies that combine exclusion (to the detriment of the lower castes and classes) and clustering (practised by people of similar socio-economic strata, or belonging to castes of similar status). This is in addition to the economic filtering mechanism, which is based on the level of income required to access the various segments of the housing market ${ }^{9}$. Today, the lines of residential segregation in the new gated communities are predominantly based on class and money (Brosius, 2010: 103). Nonetheless, as underlined by Wissink (2013: 10) in the case of Mumbai, "the emergence of the new urban enclaves [...] after liberalisation has to be understood against the background of [...] historical reality". 
Similarly, in the Chinese urban context, Wu (2005: 235) stresses that "the physical form of gating exists in the history for a long time" and further highlights the shift from enclosed work-unit compounds under the socialist period to the new commodity housing enclaves under market transition.

\title{
THE DEBATED ROLE OF THE NRIS
}

The existence of the NRIs, "a social, cultural, legal, and financial category which (....) does not exist in relation to other nation-states" is considered by King (2002: 80) as the most obvious peculiarity in India. According to this author

\begin{abstract}
"[t]his gives the new suburban phenomenon three historically distinctive characteristics: (1) it secures a flow of investment (...); (2) it helps to explain the culturally distinctive visual, spatial, typological, architectural, and naming practices of new suburban development; and (...) (3) it reaffirms the power of the state as a major contributor to the making of India's contemporary public culture". (Ibid.)
\end{abstract}

The Indian government has endeavoured to attract the investments of the Indian diaspora through relaxation of regulations since the beginning of the 1990s. However, the conditions for remitting and investing in India have changed only gradually, as did the ideological context and attitudes towards outside investments (Lall, 2001; Varrel, 2012). As a result, "even after the opening of the Indian economy NRI involvement and investment remained pathetically low" (Lall, 2001: 172). New political and economic initiatives dedicated to the diaspora marked the years 2000s (Therwath, 2011), among which was the creation in 2004 of a Ministry of Overseas Indian Affairs (MOIA) that sponsors the annual Pravasi Bharatiya Divas (Non-resident Indian Day) - a major gathering for the Indian diaspora. Subsequently 2007 saw the establishment of an investment facilitation platform for overseas Indian, the Overseas Indians Facilitation Centre, which is a public-private initiative of the MOIA and the Confederation of Indian Industry.

Private real estate developers also try to tap into the NRIs' market. To better reach these potential clients, they participate in international exhibitions and the Pravasi Bharatiya Divas, and advertise through the Internet and in the international editions of Indian magazines (King, 2002). They further multiply in their advertisements the use of foreign toponyms (such as Malibu Towne, Riverdale, Manhattan Apartmansions, Beverly Park, Windsor, Richmond, Kingston) and other symbols of a habitat and lifestyle imported from the West, as exemplified by the slogans quoted at the beginning of this paper (see also Figure 1). In such advertisements, published in 1995 in the Delhi edition of mainstream English-language newspapers, the objective is to sell the American model as a package, guaranteed, moreover, by the architects who live or have lived in North America - the sort of a habitat where everything is American in spirit, atmosphere, type and style, from the organisation of the external spaces and buildings, to the services and equipment provided, the shopping centre, interior design and comfort of the apartments, and even the bathtubs! Such publicity seems to be primarily directed at NRIs who want to invest in their mother country or are planning to return home one day or another, and who need to be reassured that the accommodation and comfort of international standards, to which they are accustomed to in the West, is available in India. More examples, including recent ones, conveying similar messages could be added (Dupont, 2005; Brosius, 2010). 
What would be the share of the NRIs' market in real estate? King (2002: 78) mentions that "in mid-1995, over 50 percent of condominium buyers were said to be NRIs". Brosius (2010: 80) proposes a similar estimate for investors in real estate in suburban Delhi. In the case of Bangalore, Varrel (2008: 290) shows however that the diaspora constitutes only a secondary market for most developers of residential compounds, usually around 10 to 15 percent of their total customers, and thus she challenges the thesis according to which the development of new residential spaces in India would respond for a large part to the NRIs' demand (ibid.).

In addition, real estate professionals may project their NRI customers in a misleading manner, in order to appeal to local customers and to justify the hike in prices, as evidenced by Nijman's analysis of the Mumbai real estate market in the 1990s (Nijman, 2000) and supported by Varrel (2012) for Bangalore. Thus, marketing material with reference to NRIs or foreign places (as those described above) are "(also) meant to impact a broader audience" (ibid: 4), and are part of marketing strategies to attract the local elite as well, by conveying an underlying message of distinction, quality and luxury. Similarly, in the branding of suburban residential developments and gated communities in China, developers use foreign names and invent "hybrid 'western' forms (...) to exploit the common social mentality that treats the western style as equivalent to a modern and high-quality environment" (Wu, 2010: 385). Beyond the actual statistics of the NRIs' market share in real estate in India and in Delhi in particular, which may be difficult to assess, the figure of the NRI does play a key role in "the real estate imaginary and politics of the 'world-class' city" (Brosius, 2010: 81). Significantly, the Indian diaspora has also helped to disseminate architectural standards and western models of housing. The new residential enclaves that have emerged in Indian metropolises thus epitomize "spaces of global cultures" (King, 2002, 2004), shaped by transnational flows - or, in the words of Emaar MGF promoting its Commonwealth Games Village, a "global living".

\section{THE APPEAL OF GATED COMMUNITIES}

The sections above expounded several factors explaining the emergence of gated communities and their success in Indian cities, with a focus on macro-economic and political factors, as well as the socio-historical context of residential segregation. In this last part, I explore this theme from the viewpoint of the residents - or as projected by the developers through their publicity hype. I also present a comparative perspective by examining in the context of Delhi some aspects debated in the context of Chinese cities, including by Sander (this volume) in the case of Shanghai. The relevance of three broad concurrent driving forces is examined: desire for security; retreat from the common city - the city of failing government as well as the polluted city; and search for prestige and distinction.

\section{Desire for Security}

The fear of crime, a thesis widely discussed in the literature on gated communities (Cséfalvay 2011; Cséfalvay and Webster, 2012; Glasze, Webster and Frantz, 2006) is considered as not adequate to explain the development of such residential forms in China ( $\mathrm{Wu}, 2010)$. Nevertheless, expatriates in Shanghai mention a "sense of security" as a positive aspect of compound living (Sander, ibid.). In the Delhi region, enclosure materialised by walls and fences as well as restricted entrance in the compound through guarded gates is an intrinsic component of the production of gated communities. Additional security devices and arrangements are highlighted in sales pitch. They respond to the growing security phobia of Delhi's well-to-do citizens and their fear of criminality - and beyond it their fear of the poor- and thus their attempts to enclose themselves in protected housing quarters, as 
observed already in other well-off neighbourhoods of the capital. Security and insecurity concerns are also omnipresent among residents of condominiums and gated communities in Bangalore (Varrel, 2008: 341). "The imperative of security has become central" (Milbert, 2009: 203, own translation) in Delhi as in other globalizing metropolises in India. This concern reflects glaring inequalities in the economic conditions and habitats of the different sections of urban society, as well as a process of increasing socio-and in some cases religious-spatial fragmentation.

\section{Retreat from Failing Government and the Polluted City}

The new private townships on the outskirts of Delhi are often presented by their developers as independent urban entities, as cities (DLF City, Sun City, Sentosa City, Rosewood City, etc.) complete with all the requisite amenities and infrastructure, and thus "self-contained" or "integrated". A careful reading of the sales pitch reveals that the amenities highlighted refer not only to exclusive recreational facilities such as sport club, swimming pool, golf course, health centre, restaurant and bar, and the like, but also to basic services such as " 24 hour water and power supply" or garbage disposal. From this angle, private neighbourhoods appear as a retreat from the metro city with its failing public services, its recurrent electricity cuts and water shortage, the everyday problems of Delhi's residents, which make the regular and guaranteed supply of trivial commodities a rare luxury, necessitating their mention in a publicity brochure. This is a distinctive feature compared to gated communities in Western countries.

The argument of privately-managed residential enclaves as an alternative to the poorlymanaged everyday city can be expanded beyond the case of Delhi. Residents of similar enclaves in Bangalore consider it essential to find a way to live to some extent outside the Indian city and its problems (Varrel, 2008: 342). As stressed by Nair (2005: 133) in the context of Bangalore as well, what is on offer in these residential enclaves but "denied to the residents of the city" is "planning itself". Margapatta City, on the outskirts of Pune in Maharashtra, further epitomises the model of a private, integrated and self-sustained city, " $a$ city within a city having commercial zone, residential neighborhoods, school, hospital, shopping malls, hotels, restaurants and recreation places", where "all the amenities and elements of modern day lifestyle that are vital for the networked society have been provided." 10

In sum, "gated communities concretise therefore the triumph of private management, restricted to an elite, over public, democratic and redistributive management" (Milbert, 2009: 210 , own translation). This supports the club-goods theory, namely the private provision of public goods and services via residential clubs as an efficient economic solution offered by gated communities (Cséfalvay 2011; Cséfalvay and Webster, 2012). In other words, gated communities constitute an "exit option" (Cséfalvay 2011) especially in the context of deficient local municipalities unable to provide adequate basic public goods and services, which is indeed a common feature of Indian cities. In the context of post-reform China, Wu (2005: 235) also analyses gated communities as the "club realm" and "a response to the state's retreat from public good provision".

However, the proliferation of 'private cities' is certainly not a solution to the challenges of urban services and their management in Indian cities. Instead, this trend is likely to contribute to increasing urban socio-spatial fragmentation. In addition, listening to residents' complaints, ${ }^{11}$ it seems that the utilities and services announced were often still inadequate, 
and at times even absent, several years after the first residents moved in.

For expatriates living in Shanghai's compounds, Sander stresses the retreat from the traffic, noise and air pollution of the city as an important incentive. Environmental considerations are equally significant to understand residential choices in the urban fringes of Delhi. They are also recurrently mobilised by real estate developers for their publicity campaigns. Despite the large scale of certain housing projects, the promoters spare no effort to expunge the urban dimension and to play down city life by highlighting the pastoral and ecological aspects. Names are reminiscent of nature and idyllic sceneries (Valley View Estate, Spring Fields, Rosewood City, Charmwood Village, etc.) and references to nature are a quasi constant feature in publicity and sales spiel. Certain recurring key words like open space, nature, air, green, clean and healthy environment appear in opposition to the words and woes associated with Delhi: polluted city, noisy, traffic jams. The two biggest real estate developers have directly integrated into their slogans or logos expressions such as: "The most environment friendly township" (DLF for its Qutab Enclave project) or "The greenest township south of Delhi'(Ansal Housing for its Sushant Lok complex). Advertisements combine bucolic images and lyrical expressions in order to touch the environmental sensibility of urbanites, tired of the pollution and congestion of Delhi. The illustrations, designs, photographs, logos or even the choice of colours and typeface reinforce the images suggested by the words ${ }^{12}$ (see Figure $3)$.

As shown by surveys conducted in DLF City in 1995-97 (Dupont, 2005; Sidhu, 1997), the search for a better quality of life and more space were reasons often cited by residents for their residential choice, particularly among those who had lived in more central (but also more congested) zones of Delhi before. No doubt, this new localization meant longer distances to the work place. But this inconvenience was compensated by the prospect of an environment more peaceful and less polluted than in the city proper even if, in reality, greens are often not as profuse and landscaped parks are not as idyllic as in the promoters' lavish publicity brochures and websites.

\section{Search for Exclusivity, Elitism and Social Homogeneity}

People's desire for exclusivity, elitism and prestige, linked to the search for a distinct identity - in Bourdieu's term, the search for "distinction" (Bourdieu 1979) - is another driving force explaining the appeal of gated communities, which has been debated in the context of western countries (Cséfalvay, 2011; Cséfalvay, Webster, 2012) and China as well. For instance, Wu (2010: 387) emphasizes that "there is a continuing need to view the gated communities not just in terms of governance issues, but also as an issue of symbolism".

In India too, as illustrated by the case of Delhi, what is sold in these new residential spaces is not only a flat or a house but a lifestyle, definitely an exclusive one, as evidenced by publicity brochures and advertisements through various media. Toponyms reminiscent of American or English urban lifestyles confer distinction and status to the residence and thereby to the residents. Other names for residential complexes have been selected from words which are symbolic of prestige and elitism (Royal Retreat, Regency Park, Golden Heights etc.). The images and specifications of sites, apartments, infrastructure and services, leisure time activities (exclusive club, swimming pool, tennis courts, golf course, etc.) and the abundant use of superlatives aim not only to guarantee modern, "world-class" standards of living but also to reinforce the ideas of luxury, excellence, and class. The profuse references to a bucolic and quiet environment (as illustrated above), which is indeed a luxury in a polluted metropolis like Delhi, also convey a privileged way of life. Elitism and exclusivity are openly advertised, 
as illustrated by two lyrical hypes among many others, from older to the most recent ones:

"And soon Delhi's most elite neighbourhood will unveil in all its grace. And you the chosen ones will acquire possession of Delhi's most sought after property. (Himurja company promoting its Kant Enclave in 1995)." "13

"The Ultimate Destination. VIP living amongst Delhi's finest. [...] This exclusive super-luxurious condominiums will rise as the pinnacle of elegance and sophistication while swaying you to world of enchanting experience. Exclusive location - Eternal bliss." (Parsvnath Landmark Developers promoting their La Tropicana in 2011) ${ }^{14}$. (see also Figure 4).

The search for selectivity and elitism in exclusive and secured residential enclaves concurs with that of security and social homogeneity (see also Nair, 2005, for Bangalore). Altogether they translate not only the desire to be protected from the 'others' (those who do not belong to the 'world-class'), but further, the desire to forget the poor, what Fernandes (2004) analyses as the "politics of forgetting" characterizing the new urban Indian middle classes.

I have noted in the case of other housing estates in Delhi the desire to live in socioeconomically homogeneous neighbourhoods. Such a residential clustering process is exacerbated in the gated communities. It is also promoted by their developers, especially when they target NRI potential buyers and aim at reassuring them that they will find in gated communities a familiar transitional space to smooth their return to the home country. Certain housing projects even go to the extent to reserve separate buildings for NRIs, thereby creating a new form of residential segregation:

"Sentosa City will also have exclusive condominium clusters for NRIs with penthouses". 15

More generally, from the mid-1990s till today, the various referents recurrently used by the promoters of secured residential enclaves in the Indian capital region, namely a blend of green utopia and modernist projections, with the assurance of international lifestyle and standards, point to urbanites belonging to a cosmopolitan elite, which is certainly not limited to the NRIs. Identity-related construction is concurrent with the promotion of gated communities reserved for the affluent classes; it also corresponds to their residents' aspirations in terms of social status and prestige.

\section{From Indian to Chinese Gated Communities: Some Common Features}

The above discussions of the emergence and the appeal of gated communities allow us to highlight a few common features in the Indian and Chinese cases. In both countries, gated communities draw on a history of residential enclosure, reinforced in India by a long tradition of social segregation. In both countries, too, the contemporary development of secured residential enclaves is a market-driven phenomena boosted by economic reforms, and responding to the failure of the state (India) or its retreat (China) as far as the provision of adequate public good and services is concerned. Beyond governance issues and the secession behaviour of the affluent, the search for exclusivity and prestige plays a major part in the success of gated communities in both cases. Consequently, there are also similarities in branding practices of Indian and Chinese real estate developers, including references to western style and names as a symbol of modernity, high quality, and distinction. In this respect, the figure of the NRI in Indian globalising metropolises further plays a specific role, which is exploited by real estate professionals. Another distinctive feature regards the security discourse, which proves to be more significant to explain the appeal of gated residential enclaves in India than in China, given an Indian urban context where glaring inequalities in 
living conditions, and in some cases the trauma of communal violence, have fuelled the fear of the poor and the 'other'.

\section{CONCLUSION: GATED COMMUNITIES IN DELHI AS IN-BETWEEN SPACES}

Gated communities in a globalising metropolis of the South like Delhi appear as "spaces of transnational cultures" (King, 2002, 2004), especially when they are homes for NRIs and other cosmopolitan urbanites. Yet, they are not a mere exogenous western production but rather places of "indigenous modernities" (to draw from the concept developed by Hosagrahar, 2005) or in-between spaces.

In the slogans and publicity hype for such residential complexes, as well as in the names given to them, signs of Indian-ness are relatively rare. In the case of Manhattan Apartmansions they have deliberately been expunged, for its promoter unashamedly proclaimed: "The only Indian thing about them is their address". ${ }^{16}$ But we should not forget that there is often a large gap between the imaginary world of the publicity hype and the reality of the suburban residential enclaves. As noted, the promised "world-class" facilities and hallmarks of elegance and luxury have at times remained on paper, and living in a gated community does not fully guarantee its residents against experiencing some of the Indian metro city's everyday challenges. Would the Indian-ness of the western-style residential complexes also reside in such a gap; an in-between space where different cultural flows intermingle?

We have seen in this paper that gated communities are also embedded in an indigenous tradition of residential segregation and enclosure. It is noteworthy that occasional references to the ancient vastu principles of architecture may even be found in the publicity for condominiums. For instance, Sentosa City was advertised as "vastu approved", and its promoter guaranteed - "Our cosmic consultant Mr. Rajesh Rya made a critical 'vastu' assessment". ${ }^{17}$ The symbols of Indian identity are more evident in the recreational places developed in the vicinity of suburban residential enclaves such as, in Gurgaon, Heritage Village Manesar, "a Rajasthani haveli [mansion] style palatial resort", Dreams ${ }^{19}$ with its Nautanki Mahal, a theatre hall "beautifully designed like an Indian Palace" and its "Culture Gully [street], a grand, plush and air conditioned" bazaar including "street performances, artisans and handicraft stores from the four corners of India". It is in these new spaces that Indian traditional architecture is reconstructed and Indian culture is revived in synthetic lavish versions, adjoin condominiums, futurist business centres, and modern shopping malls. Altogether they produce mixed landscapes, spaces in-between the global and the local.

\section{References}

Appadurai, Arjun (1996) Modernity at Large: Cultural Dimensions of Globalization, Minneapolis: University of Minnesota Press.

Atkinson, R., Blandy, S. (2006) Gated Communities. New York and London: Routledge.

Begde, P.V. (1978) Ancient and Medieval Town-Planning in India, New Delhi: Sagar Publication. 
Bourdieu, Pierre (1979) La distinction. Critique sociale du jugement. Paris : Editions de Minuit.

Brosius, Christiane (2010) India's middle class. New forms of urban leisure, consumption and prosperity, Delhi: Routledge.

Christopher, A.J. (2005) Reflections on British Imperial Geography: India and South Africa, in: Gervais-Lambony, Ph., Landy, F., Oldfiedl, S. (Eds) Reconfiguring Identities and Building Territories in India and South Africa, Delhi: Manohar, pp. 101-116.

Cséfalvay, Zoltán (2011) Gated communities for security of prestige? A public choice approach and the case of Budapest, International Journal of Urban and Regional Research, $35(4), 735-752$.

Cséfalvay, Z., Webster, C. (2012) Gates or no gates? A cross-European enquiry into the driving forces behind gated communities. Regional Studies 46(3), 293-308.

DDA (2007) Master Plan for Delhi 2021. Delhi: Delhi Development Authority [As Notified on $7^{\text {th }}$ February, 2007. Vide S.O. No 141 published in Gazette of India Extraordinary [Part II - Section 3 - Sub-Section (ii)].

Dupont, Véronique (2004) Socio-spatial differentiation and residential segregation in Delhi: a question of scale?, Geoforum, 35(2), 157-175.

Dupont, Véronique (2005) The idea of a new chic Delhi through publicity hype, in: Koshla, R. (Ed), The Idea of Delhi, Mumbai: Marg Publications, pp. 78-93.

Dupont, Véronique (2011) The dream of Delhi as a global city, International Journal of Urban and Regional Research, 35(3), 533-554.

Evenson, Norma (1989) The Indian Metropolis, A view toward the West, New Haven and London: Yale University Press.

Fernandes, Leela (2004) The politics of forgetting: class politics, state power and the restructuring of urban space in India, Urban Studies 41(12), 2415-2430.

Gayer, L., Jaffrelot, Ch. (2012) Introduction. Muslims of the Indian city: from centrality to marginality, in: Gayer, L., Jaffrelot, Ch. (Eds) Muslims in Indian Cities. Trajectories of Marginalisation, New Delhi: Harper Collins, pp. 1-22.

Glasze, G., Webster, C., Frantz, K. (Eds) (2006) Private Cities. Global and local perspectives, New York: Routledge.

Hosagrahar, Jyoti (2005) Indigenous Modernities. Negotiating architecture and urbanism, London and New York: Routledge [Architext].

Jaffrelot, Ch., Thomas, Ch. (2012) Facing ghettoization in 'riot-city'. Old Ahmedabad and Juhapura between victimisation and self-help, in: Gayer, L., Jaffrelot, Ch. (Eds) Muslims in Indian Cities. Trajectories of Marginalisation, New Delhi: Harper Collins, pp. 43-79. 
King, Anthony D. (2002) Speaking from the margins: 'Postmodernism', transnationalism, and the imagining of contemporary Indian urbanity, in: Grant, R. and J. Rennie, J. (Eds), Globalization and the Margins, Basingstoke and New York: Palgrave Macmillan, pp. 72-90.

King, Anthony D. (2004). Transnational Delhi Revisited: the spatial language of three modernities, In: King, A.D. Spaces of global cultures: Architecture, Urbanism, Identity, London and New York: Routledge [Architext], pp. 141-160.

Kothari, S., Sethi, H. (1985) Voices from a Scarred City. The Delhi Carnage in Perspective. Delhi: Lokayan.

Lall, Marie-Carine (2001) India's missed opportunity. Aldershot: Ashgate.

Mahadevia, Darshini (2007) A city with many borders - Beyond ghettoisation in Ahmedabad, in: Shaw, A. (Ed) Indian Cities in Transition, Hyderabad \& Chennai: Orient Longman, pp. 340-389.

Milbert, Isabelle (2009) Inde: les villes fermées, la nouvelle norme?, in : Pacquot, T. (Ed) Ghettos de riches. Tour du monde des enclaves résidentielles sécurisées, Paris: Perrin, pp. 193-212.

Mitra, Asok (1970) Delhi. Capital City. New Delhi: Thomson Press.

Nagpaul, Hans (1988) Delhi, in: Dogan, M., J.D Kasarda, J.D. (Eds), The Metropolis Era. Volume 2. Mega-Cities, Newbury Park: Sage, pp. 184-211.

Nair, Janaki (2005) The Promise of the Metropolis. Bangalore's Twentieth Century, New Delhi: Oxford University Press.

Nijman, Jan (2000) Mumbai's Real Estate Market in 1990s: De-Regulation, Global Money and Casino Capitalism, Economic and Political Weekly, 35(7), 575-582.

Sidhu, Mriga (1997) "In-depth interviews on environmental factors and residential practices. Vol. III: DLF Qutab Enclave, Gurgaon - A residential complex" [Survey on spatial mobilities in the metropolitan area of Delhi. Working Paper $N^{\circ}$ 5]. New Delhi: ORSTOM-IEG, mimeo.

Therwath, Ingrid (2011) The Indian State and the Diaspora: Towards a New Political Model, in: Leclerc, E. (Ed.), International and Transnational Political Actors: Case Studies from the Indian Diaspora, New Delhi: Manohar, pp. 45-63.

Varrel, Aurélie (2008) "Back to Bangalore". Etude géographique de la migration de retour des Indiens très qualifiés à Bangalore (Inde). Poitiers: University of Poitiers, Department of Geography, mimeo.

Varrel, Aurélie (2012) NRIs in the City. Identifying International Migrants' Investments in the Indian Urban Fabric, South Asia Multidisciplinary Academic Journal [Online] 6 [URL: http://samaj.revues.org/3425] 
Wissink, Bart (2013) Enclave urbanism in Mumbai: An Actor-Network-Theory analysis of urban (dis) connection, Geoforum 47(June), 1-11.

Wu, Fulong (2005) Rediscovering the 'gate' under market transition: from work-unit compounds to commodity housing enclaves. Housing Studies, 20(2), 235-254.

Wu, Fulong (2010) Gated and packaged suburbia: Packaging and branding Chinese suburban residential development, Cities 27(5), 385-396.

\footnotetext{
${ }^{1}$ Italics for quotations indicate that those are drawn from publicity hypes by the promoters of residential estates.
}

${ }^{2}$ Advertisement by S. Sagar Suri Group, published in the Delhi edition of the Times of India, 14 January 1995. See Figure 1.

3 Advertisement by Malibu Estates Private Limited, published in The Pioneer, Delhi, 24 December 1995.

${ }^{4}$ See http://www.emaarmgf.com/cgv (accessed 22 August 2011 and 22 March 2014) and Figure 2.

${ }^{5}$ In the Indian context, 'middle class' is often a euphemism for upper-middle class or the well-off sections of the urban society.

${ }^{6}$ See for instance 'La Tropicana' condominium built by Parsvnath Landmark Developers (http://www.parsvnath.com/residential/delhi/parsvnathlatropicana/overview.asp?pr=latropicana, last accessed on 22.08.2011) on a site just adjoining the previous Durga Basti, a slum of more than 1700 families demolished in 2001.

${ }^{7}$ See for instance the DLF project 'Capital Greens' and 'DLF Tower' on Shivaji Marg : http://www.capitalgreensdlf.in/ Accessed 22 August 2011.

${ }^{8}$ See http://www.emaarmgf.com/cgv Accessed 22 August 2011 and 22 March 2014.

${ }^{9}$ For a detailed analysis of the pattern of segregation in Delhi, see Dupont (2004).

${ }^{10}$ See http://www.magarpattacity.com/ Accessed 24 August 2011.

11 Source: interviews conducted in DLF City in 1997 and shared experiences periodically reported in newspaper articles or posted on dedicated websites. See for instance: http://www.jagrancityplus.com/ Accessed 24 August 2011.

12 For a detailed analysis of publicity hype regarding the new residential spaces on the outskirts of Delhi, see Dupont (2005).

${ }^{13}$ Advertisement published in The Hindu, Real Estate National Capital Region, Delhi, 30 October 1995.

$14 \quad$ See: $\quad$ http://www.parsvnath.com/residential/delhi/parsvnathlatropicana/overview.asp?pr=latropicana Accessed 22 August 2011.

${ }^{15}$ Advertisement by the developer Growth Techno Project, published in the Delhi edition of The Pioneer on 18 December 1996. Eventually Sentosa City project did not come up, as the Ghaziabad Development Authority cancelled the agreement with its developer in 1997.

${ }^{16}$ Sales brochure published by the developer Unitech in 1994. 
${ }^{17}$ Advertisement by the developer Growth Techno Project, published in the Delhi edition of The Pioneer on 18 December 1996 (see note 15).

${ }^{18}$ See: http://manesar.selecthotels.co.in/ Accessed 26 August 2011.

${ }^{19}$ See: http://www.gurgaonsite.com/kingdom-of-dreams.html Accessed 26 August 2011. 